\title{
Impacts of Mild Hypothermia on LPS-Mediated TLR4/NF-kB Signaling Pathway in Microglia
}

\author{
Li Liu, Xiaoshuang Li, Yaoyao Wang, Fang Cao, Shihai Zhang, Zhen Zhan, Yangyang Meng, \\ Qilian Xie*
}

Emergency Medical Center, The Affiliated Provincial Children's Hospital of Anhui Medical University, Hefei, China

Email: *xieqilian123@sina.com

How to cite this paper: Liu, L., Li, X.S., Wang, Y.Y., Cao, F., Zhang, S.H., Zhan, Z., Meng, Y.Y. and Xie, Q.L. (2019) Impacts of Mild Hypothermia on LPS-Mediated TLR4/NF-kB Signaling Pathway in Microglia. Journal of Biosciences and Medicines, 7, 86-97.

https://doi.org/10.4236/jbm.2019.72008

Received: December 20, 2018

Accepted: February 19, 2019

Published: February 22, 2019

Copyright $\odot 2019$ by author(s) and Scientific Research Publishing Inc. This work is licensed under the Creative Commons Attribution International License (CC BY 4.0).

http://creativecommons.org/licenses/by/4.0/

\begin{abstract}
Background: Existing studies have found that some inflammatory factors cause brain cell damage through the TLR4/NF- $\mathrm{KB}$ pathway, and that mild hypothermia has a protective effect on nerve cells. It is not clear whether the mild hypothermic brain protection is achieved through the TLR4/NF- $\mathrm{kB}$ pathway in microglia. Objective: To investigate the impacts of mild hypothermia on lipopolysaccharide (LPS)-mediated TLR4/NF- $\kappa B$ signaling pathway in microglia. Method: The cultured microglia cells in vitro were divided into the NS group and the LPS group at $33^{\circ} \mathrm{C}$ and $37^{\circ} \mathrm{C}$, respectively; quantitative RT-PCR was performed to detect the expressions of TLR4 and NF- $\mathrm{kB}$ mRNA in the microglia, Western blot was used to detect the expressions of TLR4 and NF- $\kappa B$ protein in the microglia, and ELISA was performed to detect the levels of tumor necrosis factor $\alpha$ (TNF- $\alpha$ ) and interleukin-10 (IL-10) in the culture medium. Results: Under the LPS stimulation, the mRNA and protein expressions of TLR4 and NF- $\mathrm{KB}$ at different time points had significant changes between the normothermia group and the mild hypothermia group, in which the expressions in the former group were firstly increased and then decreased, while those in the latter showed a continuous increasing trend $(\mathrm{P}<0.01)$; and the expressions of TNF- $\alpha$ in all the groups presented the trend of first-increasing then-decreasing, while IL-10 exhibited one slow linear increasing trend $(\mathrm{P}<0.01)$. Conclusions: Mild hypothermia could inhibit the mRNA and protein expressions of LPS-mediated TLR4/NF- $\mathrm{kB}$ signaling pathway in the microglia, and inhibit the production and release of downstream inflammatory cytokines (TNF- $\alpha$ and IL-10).
\end{abstract}

\section{Keywords}

Hypothermia, Lipopolysaccharide, Microglia, Toll-Like Receptor 4, NF-кB, Tumor Necrosis Factor- $\alpha$, Interleukin-10 


\section{Introduction}

The large amount releasing of LPS is the main reason of G-bacterial infection caused sepsis associated encephalopathy (SAE) [1] [2], in which the released LPS could specifically activate the main immune effector cells-microglia (MG) in the central nervous system (CNS); through identifying and binding the Toll-like receptor 4 complex (TLR4) on the MG cell membrane, LPS could then activate the intracellular MyD88-dependent and non-dependent signaling pathways, activate the downstream signaling molecule Toll-like receptor 4 and a series of biological effects, thus releasing huge amounts of inflammatory cytokines such as tumor necrosis factor- $\alpha$ (TNF- $\alpha$ ), interleukin $1 \beta$ (IL- $1 \beta$ ), and interleukin-10 (IL-10), as well as such cytotoxic substances as peroxides and oxygen free radicals. So LPS is considered as the main instigator and participant towards brain inflammations, plays an important role in the occurrence and development of CNS diseases, and leads to the CNS damages [3] [4] [5]. Under stationary status, MG plays a major role of immune surveillance, and the early activated MG plays the roles of phagocytizing cell debris, releasing neurotrophic factors, protecting and promoting tissue repair, but the excessively activated MG would release a large number of pro-inflammatory substances, thus directly or indirectly causing secondary neuronal injury, thus being involved in the occurrence and development of CNS diseases [6] [7]. Numerous studies had shown that inhibiting the MG activation-induced inflammations and oxidative stress could reduce the extent of nerve damages [8] [9] [10] [11] [12]; therefore, regulating the immune inflammatory responses in CNS had become a target for the treatment of CNS disorders [13] [14]. Mild hypothermia could reduce the metabolic rate of cells, inhibit the release of excitatory neurotransmitter Glu and free radicals, improve the cerebral blood flow, reduce the cerebral edema, protect the blood-brain barrier, and block the apoptosis, etc., thereby slowing the development speed and degree of nerve inflammatory responses in general, and gaining time for protecting the nerve cell functions and further comprehensive treatment; meanwhile, it could also significantly reduce the cerebral ischemia-reperfusion injury and improve the prognosis during the processes of cerebral infarction, toxic encephalopathy, and cardiopulmonary resuscitation [15] [16], so it was recommended as the first class I evidence in the treatment of hypoxic-ischemic encephalopathy and neonatal asphyxia after cardiopulmonary resuscitation [17] [18]. Current, remedial mild hypothermia therapy has become a hot spot in treating acute brain injury, although its protective effects are exact, its specific mechanisms are still unclear. This study mainly investigated whether mild hypothermia could downregulate the expressions of inflammatory substances in the activated MG's TLR4/NF- $\mathrm{KB}$ signaling pathway, thereby reducing the CNS inflammations.

\section{Materials and Methods}

\subsection{Reagents and Drugs}

LPS was purchased from Sigma; DMEM high-glucose medium was purchased 
from Gibco; FBS (fetal bovine serum) was purchased from Australia Origin; Dimethylsulfojdde (DMSO) was purchased from Amresco; total RNA extraction TRIzol reagent was purchased from Life Technologies; the first strand cDNA synthesis kit was purchased from TaKaRa; real-time quantitative PCR (qRT-PCR) kit was purchased from Sunshine biotechnology Co. Ltd.; Quantitative ELISA kits of Mice TNF- $\alpha$ and IL-10 were provided by R \& D systems (Minneapolis, MN, USA); mouse anti-TLR4 antibody, mouse anti-NF- $\mathrm{KB}$, and HRP labeled goat anti-mouse antibody were purchased from Abcam; chemiluminescent fluid was purchased from Thermo.

\subsection{Cell Culture and Intervention}

MG were isolated from the brain tissues of newborn rats (SPF grade, 1 - 3 days old) referring to the previous report [19]: sampled all the brain tissues, rinsed, and stripped the piamater and blood vessels carefully under one dissecting microscope; removed the residual blood, transferred and soaked the tissues into a penicillin-filling vial; cut and pipetted the separated brain tissues; after digested with trypsin, filtrated, centrifuged and discarded the supernatant; re-suspended the precipitate in 10\% FBS-containing DMEM culture medium (three brain tissues/per culture flask) and cultured at $37^{\circ} \mathrm{C}$ and $5 \% \mathrm{CO}_{2}$ for $2-3$ weeks; changed the medium once every 2 - 3 days and observed the cells' growth state under an inverted microscope; performed trypsin digestion and vibrated the culture flask, then collected the cell suspension into a centrifuge tube; centrifuged at 1000 $\mathrm{r} / \mathrm{min}$ for $10 \mathrm{~min}$, collected and transferred the cells into 10\% FBS-containing culture flask for 12-hour stand culture; rinsed twice, changed the medium, and removed the non-adherent cells, including the astrocytes; cultured the rest cells in an thermostated incubator. The cultured cells were then seeded in one $6-\mathrm{cm}$ dish (with $5 \mathrm{ml}$ of $10 \%$ FBS-containing DMEM), and cultured at $37^{\circ} \mathrm{C}$ and $5 \%$ $\mathrm{CO}_{2}$, and passaged the cells every $48 \mathrm{~h}$. When the cells were in good growing conditions, inoculated the cells into the culture dish $\left(5 \times 10^{6} \mathrm{cells} / \mathrm{dish}\right)$ and cultured for $24 \mathrm{~h}$ for the experiments. The cells were divided into the normothermia control group $\left(37^{\circ} \mathrm{C}-\mathrm{NS}\right)$, the normothermia intervention group $\left(37^{\circ} \mathrm{C}-\mathrm{LPS}\right)$, the mild hypothermia control group $\left(33^{\circ} \mathrm{C}-\mathrm{NS}\right)$, and the mild hypothermia intervention group $\left(33^{\circ} \mathrm{C}\right.$-LPS). The stimulation concentration of LPS was 10 $\mathrm{ng} / \mathrm{ml}$ [20]. The $37^{\circ} \mathrm{C}-\mathrm{NS}$ group was cultured at $37^{\circ} \mathrm{C}$ and $5 \% \mathrm{CO}_{2}$, while the $33^{\circ} \mathrm{C}$-NS group was cultured at $33^{\circ} \mathrm{C}$ and $5 \% \mathrm{CO}_{2}$. Each group was sampled after 0-h, 2-h, 6-h, 12-h, 24-h culture for the measurement, with 0 -h as the starting time point of intervention. Each experiment was set 3-repeated dishes, and all the experiments were repeated three times.

\subsection{Expression Detection of TLR4 and NF- $\kappa B$ mRNA by RT-qPCR}

Extracted the total RNA using TRIzol; after detected the concentration and purity by spectrophotometer, performed the reverse transcription to synthesize the first strand CDNA; confirmed the PCR amplification fragments by $3 \%$ agarose 
gel. The primer sequences were independently designed and synthetized by Sangon Biotech (Shanghai) Co., Ltd. The target TLR4 gene: sense primer: 5'-CCTGATGACATTCCTTCTTC-3', antisense primer:

5'-TTGAGAGGTGGTGTAAGC-3', amplified fragment: $172 \mathrm{bp}$; the target NF-kB gene: sense primer: 5'-AAAGGTTATCGTTCAGTTGGT-3', antisense primer: 5'-TAATACACGCCTCTGTCATC-3', amplified fragment: $209 \mathrm{bp}$; housekeeping gene glyceraldehyde 3-phosphate catalase (GAPDH): sense primer: 5'-ATCAAGAAGGTGGTGAAGCA-3', antisense primer:

5'-AGGTGGAAGAGTGGGAGTTG-3', amplified fragment: $113 \mathrm{bp}$. RT-qPCR reaction conditions: $95^{\circ} \mathrm{C}$ for $10 \mathrm{~min}, 95^{\circ} \mathrm{C}$ for $15 \mathrm{~s}, 60^{\circ} \mathrm{C}$ for $40 \mathrm{~s}$, with 40 standard cycles. The $2^{-\Delta \Delta C t}$ method was used to relatively quantify the expression levels of TLR4, NF- $\kappa$ B and GAPDH.

\subsection{Expression Detection of TLR4 and NF-кB Protein by Western Blot}

Extracted the total proteins at each sampling time point, after detected the protein content using Coomassie brilliant blue method, sampled10ul of protein specimens for 10\% SDS-PAGE electrophoresis, respectively; after the electrophoresis, transferred the proteins onto one nitrocellulose membrane, closed with $5 \%$ skim milk $+2 \%$ goat serum for 1 hour; incubated with the primary antibodies overnight at $4^{\circ} \mathrm{C}$, rinsed with TNST for $3 \times 5 \mathrm{~min}$; incubated with the secondary antibodies in darkness at room temperature for $2 \mathrm{~h}$, rinsed with TNST for $6 \times 5$ min; scanned using the Odyssey bicolor infrared laser imaging system, and used the Quantity One image analysis system to measure the gray values; used GAPDH as the internal control to reflect the expressions of the target proteins.

\subsection{Detection of Inflammatory Cytokines by ELISA}

Extracted the culture supernatant at each designed time point for the measuring the levels of TNF- $\alpha$ and IL-10 levels referring to the ELISA kit instructions; used the Curve Expert 1.3 software for the fitting of the standard ELISA curve.

\subsection{Statistical Analysis}

GraphPad Prism 5.0 statistical software was used for data processing; the data were expressed as mean \pm standard error $(\bar{x} \pm s)$. The comparison of statistical data used the paired t test or ANOVA, with $\mathrm{P}<0.05$ considered as statistically significant.

\section{Results}

\subsection{Expressions of TLR4 and NF- $\kappa B$ mRNA at Different Time Points in Each Group}

As shown in Figure 1, the expressions of TLR4 and NF- $\mathrm{kB}$ mRNA in the $37^{\circ} \mathrm{C}$-NS group and the $33^{\circ} \mathrm{C}-\mathrm{NS}$ group did not appear significant change when lacked the LPS stimulation, and the differences between these two groups at each 


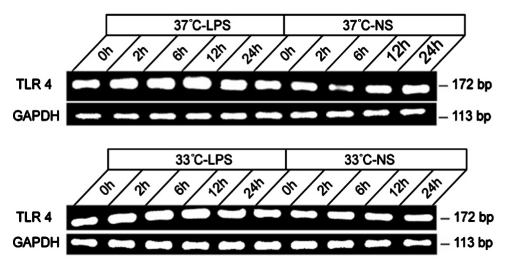

(a)

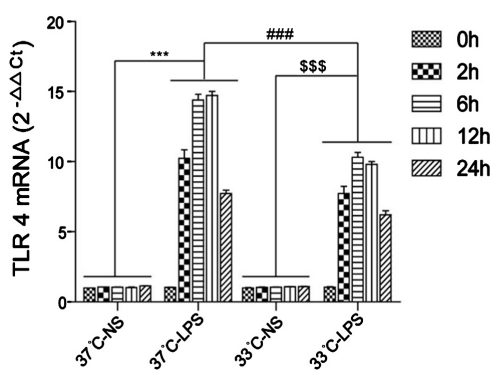

(b)

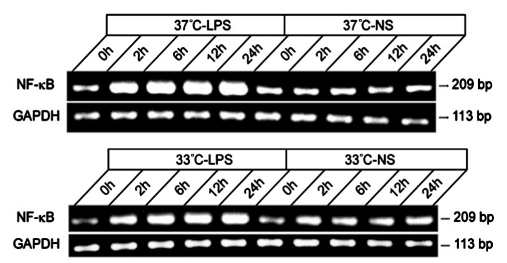

(c)

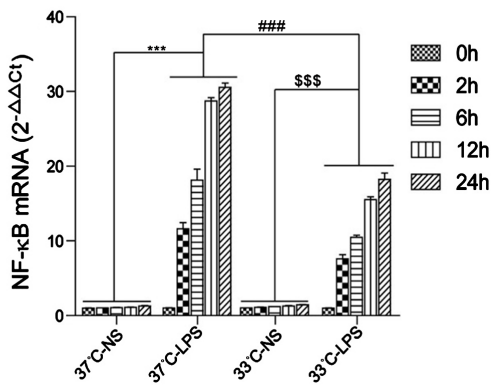

(d)

Figure 1. Expressions of TLR 4 receptor mRNA and NF- $\kappa B$ mRNA in each group at different time points. (a) Electrophoresis results of the RT-qPCR products of TLR4 receptor mRNA in the $37^{\circ} \mathrm{C}$-NS group (upper) and the $33^{\circ} \mathrm{C}$-NS group (lower); (b) Relative abundance of TLR4 receptor mRNA on GAPDH protein mRNA, $2^{-\Delta \Delta \mathrm{Ct}}$; (c) Electrophoresis results of the RT-qPCR products of NF- $\mathrm{kB}$ mRNA in the $37^{\circ} \mathrm{C}-\mathrm{NS}$ group (upper) and the $33^{\circ} \mathrm{C}-\mathrm{NS}$ group (lower); (d) Relative abundance of NF- $\kappa \mathrm{B}$ mRNA on GAPDH protein mRNA, $2^{-\Delta \Delta \mathrm{Ct}}$. ${ }^{* *}$ : the $37^{\circ} \mathrm{C}$-LPS group vs. the $37^{\circ} \mathrm{C}-\mathrm{NS}$ group, $\mathrm{P}<0.001 ; \$ \$ \$$ : the $33^{\circ} \mathrm{C}$-LPS group vs. the $33^{\circ} \mathrm{C}$-NS group, $\mathrm{P}<0.001$; \#\#\#: the $37^{\circ} \mathrm{C}$-LPS Group vs. the $33^{\circ} \mathrm{C}$-LPS group, $\mathrm{P}<0.001$; Note: TLR4: toll-like receptor 4 ; NF- $\mathrm{kB}$ : nuclear factor $\mathrm{B}$; GAPDH: glyceraldehyde 3-phosphate catalase; LPS: lipopolysaccharide; NS: normal saline; normal temperature: room temperature: $37^{\circ} \mathrm{C}$; mild hypothermia: $33^{\circ} \mathrm{C}$.

time point were not statistically significant $(\mathrm{P}>0.05)$. When stimulated by LPS, the $37^{\circ} \mathrm{C}$-NS group and the $33^{\circ} \mathrm{C}-\mathrm{NS}$ group showed significant changes at each time point. TLR4 exhibited the trend of first-increasing then-decreasing (Figure 1(a) and Figure 1(b)), while NF- $\kappa B$ showed one continuous increasing trend (Figure 1(c) and Figure 1(d)), Compared with the control group in different time points, the expression of TLR4 and NF- $\mathrm{kB}$ mRNA decreased significantly and the difference was statistically significant $(\mathrm{P}<0.01)$.

\subsection{Expressions of TLR4 and NF-אB Protein at Different Time Points in Each Group}

As shown in Figure 2, the expressions of TLR4 and NF- $\mathrm{KB}$ protein in the $37^{\circ} \mathrm{C}$-NS group and the $33^{\circ} \mathrm{C}$-NS group did not appear significant change when lacked the LPS stimulation, and the differences between these two groups at each time point were not statistically significant $(\mathrm{P}>0.05)$. When stimulated by LPS, the $37^{\circ} \mathrm{C}$-NS group and the $33^{\circ} \mathrm{C}-\mathrm{NS}$ group showed significant changes at each time point. TLR4 exhibited the trend of first-increasing then-decreasing (Figure 2(a) and Figure 2(b)), while NF- $\mathrm{B}$ B showed one continuous increasing trend (Figure 2(c) and Figure 2(d)), Compared with the control group in different time points, the expression of TLR4 and NF- $\mathrm{kB}$ protein decreased significantly and the difference was statistically significant $(\mathrm{P}<0.01)$. 


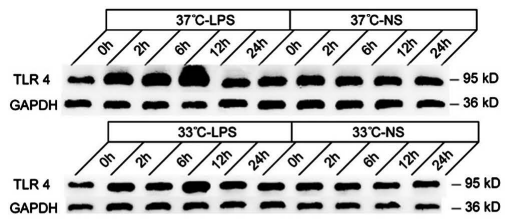

(a)

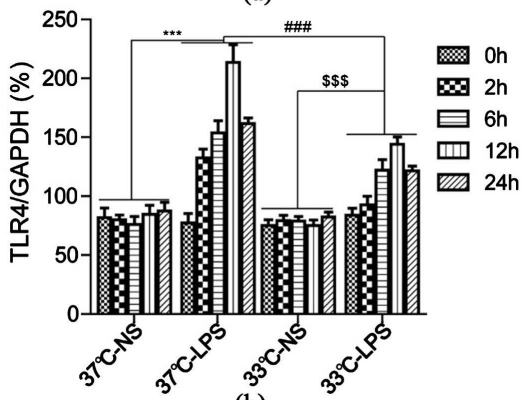

(b)

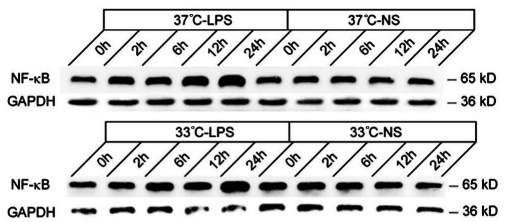

(c)

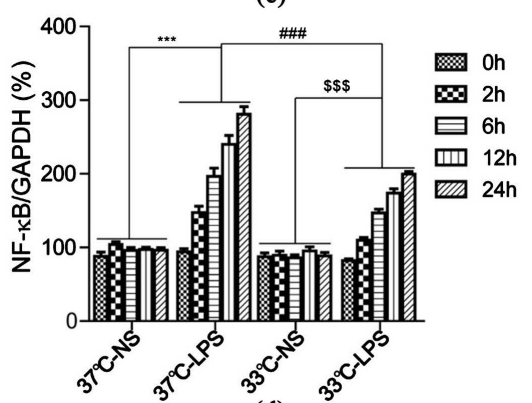

(d)

Figure 2. Expressions of TLR 4 receptor and NF- $\kappa B$ protein in each group at different time points by western blot. (a) Western blot results of TLR4 receptor protein in the $37^{\circ} \mathrm{C}-\mathrm{NS}$ group (upper) and the $33^{\circ} \mathrm{C}-\mathrm{NS}$ group (lower); (b) Relative grey value of TLR4 receptor protein on GAPDH protein (\%); (c) Western blot results of NF- $\kappa$ B protein in the $37^{\circ} \mathrm{C}-\mathrm{NS}$ group (upper) and the $33^{\circ} \mathrm{C}-\mathrm{NS}$ group (lower); (d) Relative grey value of NF- $\kappa \mathrm{B}$ protein on GAPDH protein (\%). ${ }^{* * *}$ : the $37^{\circ} \mathrm{C}$-LPS group vs. the $37^{\circ} \mathrm{C}-\mathrm{NS}$ group, $\mathrm{P}<$ $0.001 ; \$ \$$ : the $33^{\circ} \mathrm{C}$-LPS group vs. the $33^{\circ} \mathrm{C}$-NS group, $\mathrm{P}<0.001$; \#\#\#: the $37^{\circ} \mathrm{C}-\mathrm{LPS}$ Group vs. the $33^{\circ} \mathrm{C}-L P S$ group, $\mathrm{P}<0.001$; Note: TLR4: toll-like receptor 4; NF-kB: nuclear factor B; GAPDH: glyceraldehyde 3-phosphate catalase; LPS: lipopolysaccharide; NS: normal saline; normal temperature: room temperature: $37^{\circ} \mathrm{C}$; mild hypothermia: $33^{\circ} \mathrm{C}$.

\subsection{Contents of TNF- $\alpha$ and IL-10 at Different Time Points in Each Group}

As shown in Table 1, the expressions of TNF- $\alpha$ in the $37^{\circ} \mathrm{C}$-NS group and the $33^{\circ} \mathrm{C}-\mathrm{NS}$ group exhibited the similar trend when lacked the LPS stimulation, and there was statistically significant difference (all $\mathrm{P}$ values $>0.05$ ). When stimulated by LPS, the TNF- $\alpha$ content in the $37^{\circ} \mathrm{C}-\mathrm{NS}$ group reached the peak at $2 \mathrm{~h}$, while that in the $33^{\circ} \mathrm{C}$-NS group reached the peak at $6 \mathrm{~h}$, and the peak was significantly lower than that in the $37^{\circ} \mathrm{C}-\mathrm{NS}$ group. Except for the contents at $0 \mathrm{~h}$, the differences in the TNF- $\alpha$ content at other sampling time points between the two group were statistically significant $(\mathrm{P}<0.01)$.

As for the releasing of IL-10, as shown in Table 2, when lacked the LPS stimulation, the release of IL-10 in the two groups showed one slow linear change, and no difference could be found at each time point between the two groups $(\mathrm{P}>0.05)$. When stimulated by LPS, the $37^{\circ} \mathrm{C}-\mathrm{NS}$ group and the $33^{\circ} \mathrm{C}$-NS group both showed continuous increasing trend of the IL-10 release; except for the contents at $0 \mathrm{~h}$, the differences in the IL-10 content at other sampling time points between the two groups were statistically significant $(\mathrm{P}<0.01)$.

\section{Discussion}

SAE is a common complication of sepsis mainly characterized by the systemic inflammatory response caused diffuse brain dysfunction. The mortality of SAE 
Table 1. Changes of serum TNF- $\alpha$ at other sampling time points $(\mathrm{pg} / \mathrm{ml})$.

\begin{tabular}{cccccc}
\hline \multirow{2}{*}{ Group } & \multicolumn{5}{c}{ Time points } \\
\cline { 2 - 6 } & $0 \mathrm{~h}$ & $2 \mathrm{~h}$ & $6 \mathrm{~h}$ & $12 \mathrm{~h}$ & $24 \mathrm{~h}$ \\
\hline $37^{\circ} \mathrm{C}$-NS & $8.70 \pm 0.61$ & $12.96 \pm 0.65$ & $15.75 \pm 0.98$ & $18.55 \pm 1.51$ & $22.61 \pm 3.06$ \\
$37^{\circ} \mathrm{C}-\mathrm{LPS}$ & $8.55 \pm 0.50$ & $17.90 \pm 0.64$ & $94.53 \pm 3.13$ & $120.41 \pm 5.44$ & $177.65 \pm 5.52$ \\
$33^{\circ} \mathrm{C}-\mathrm{NS}$ & $8.56 \pm 0.55^{*}$ & $11.62 \pm 0.43$ & $13.36 \pm 1.02$ & $16.79 \pm 1.21$ & $18.99 \pm 1.57$ \\
$33^{\circ} \mathrm{C}$-LPS & $9.65 \pm 0.52$ & $11.99 \pm 0.48$ & $55.87 \pm 2.39$ & $65.44 \pm 1.52$ & $88.18 \pm 3.98$ \\
\hline
\end{tabular}

Note: The expressions of TNF- $\alpha$ in the $37^{\circ} \mathrm{C}-\mathrm{NS}$ group and the $33^{\circ} \mathrm{C}$-NS group exhibited the similar trend when lacked the LPS stimulation ( $\mathrm{P}>0.05$ ). The TNF- $\alpha$ contents in the $37^{\circ} \mathrm{C}$-LPS group and the $33^{\circ} \mathrm{C}$-LPS group exhibited the first-increasing then-decreasing trend with time extending, but the peak of TNF- $\alpha$ content in the $33^{\circ} \mathrm{C}$-LPS group was decreased and delayed, and difference at each time point between the two groups was statistically significant $(\mathrm{P}<0.01)$.

Table 2. Changes of serum IL-10 at other sampling time points ( $\mathrm{pg} / \mathrm{ml})$.

\begin{tabular}{cccccc}
\hline \multirow{2}{*}{ Group } & \multicolumn{5}{c}{ Time points } \\
\cline { 2 - 6 } & $0 \mathrm{~h}$ & $2 \mathrm{~h}$ & $6 \mathrm{~h}$ & $12 \mathrm{~h}$ & $24 \mathrm{~h}$ \\
\hline $37^{\circ} \mathrm{C}-\mathrm{NS}$ & $13.20 \pm 1.10$ & $18.91 \pm 1.83$ & $22.89 \pm 1.83$ & $28.24 \pm 3.02$ & $27.51 \pm 3.44$ \\
$37^{\circ} \mathrm{C}$-LPS & $12.44 \pm 0.97$ & $25.65 \pm 2.49$ & $61.66 \pm 1.43$ & $110.82 \pm 2.60$ & $139.92 \pm 5.39$ \\
$33^{\circ} \mathrm{C}-\mathrm{NS}$ & $14.07 \pm 1.45$ & $14.96 \pm 1.14$ & $18.39 \pm 0.99$ & $23.58 \pm 1.96$ & $27.06 \pm 2.01$ \\
$33^{\circ} \mathrm{C}-\mathrm{LPS}$ & $13.14 \pm 1.75$ & $19.35 \pm 1.19$ & $41.16 \pm 2.86$ & $78.03 \pm 1.77$ & $98.06 \pm 2.52$ \\
\hline
\end{tabular}

Note: The IL-10 contents in the $37^{\circ} \mathrm{C}$-NS group and the $33^{\circ} \mathrm{C}$-NS group were gradually increased with the intervention time extending, and the content in the $33^{\circ} \mathrm{C}$-NS group at each time point was relatively higher than the $37^{\circ} \mathrm{C}$-NS group, and the differences were statistically significant $(\mathrm{P}<0.01)$.

patients was significantly higher than those without encephalopathy, its pathogenesis was still not clear yet, and there was no specific treatment towards it [2] [21] [22] [23]. Lots of in vivo and in vitro experiments had demonstrated that mild hypothermia had protective effects towards sepsis, acute lung injury, acute pancreatitis, acute cerebral infarction, and brain injury, etc., [15] [17] [18] [24]-[30], and blocking TLR4 also showed certain protective effects towards the acute inflammatory diseases [31] [32]. But so far, few studies had investigated the protective mechanisms of remedial mild hypothermia towards the endotoxin induced brain injury, including whether mild hypothermia might have certain impacts on the transcriptions and expressions of the TLR4 signaling pathway in the endotoxin-activated MG. One study had shown that the uncontrolled releasing of inflammatory mediators was one of the pathogeneses of sepsis; these cytokines could enter the brain, stimulate the glial cells and the neurons to secrete large amounts of cytokines [33]; when CNS was infringed by the pathogens, TNF- $\alpha$ was essential towards the body defense and neuron protection, but the excessively produced TNF- $\alpha$ would injury the endothelial cells, thus destructing the blood-brain barrier and enhancing the permeability of the blood-brain barrier; meanwhile, it might mediate the destruction of the myelin sheath and the oligodendrocytes [34]; it could also act on the cerebral vascular endothelial cells, resulting in the destruction of the blood-brain barrier, so that 
the LPS and inflammatory mediators in the peripheral blood could largely enter the brain to activate the microglia and astrocytes, thus further aggravating the inflammatory responses in the brain and creating vicious cycles [35] [36]. MG-secreted IL-10 in the late stage could inhibit the immune inflammatory responses and promote the tissue repairing [37]. Numerous studies had shown that [38] [39] LPS could induce the massive release of the inflammatory factors, and the LPS concentration used in this study was $10 \mu \mathrm{g} / \mathrm{mL}$, which could better induce the viability of MG.

It's well known that [3] [4] [5] MG was the main immune cells in CNS, and its surface mainly expressed TLR4. TLR4 belongs to the Toll-like receptor family, after stimulated by LPS, it could activate a variety of signaling pathways, and would eventually be activated by the hydrolysis of NF- $\mathrm{KB}$ suppression protein; the activated NF- $\kappa B$ would immediately translocate into nuclei, start gene transcription, and upregulate the expressions of a series of cytokines and chemokines [40] [41]. The study found that after the LPS stimulation, the transcription and expression of NF- $\mathrm{kB}$ in both groups were gradually increased with time extending. However, the increasing trend in the mild hypothermia group was significantly lower than the normothermia group, which might be related with the fact that mild hypothermia reduced the activation and transcription of TLR4 protein, or directly inhibited the hydrolysis of NF-kB-conjunctive suppression protein; the above presumptions still needed further studies.

This study used MG for the in vitro experiment, through detecting the expressions of TLR4 and NF- $\mathrm{kB}$ mRNA, as well as the levels of TNF- $\alpha$ and IL-10, in order to explore the impacts of mild hypothermia on the CNS inflammatory responses. The results showed that when under the LPS stimulation, the expressions of both TNF- $\alpha$ and IL-10 in the two groups were significantly increased, while at the same time point, the levels of TNF- $\alpha$ and IL-10 in the mild hypothermia group were lower than the normothermia group, and it was because mild hypothermia could inhibit the transcription and expression of TLR4mRNA, and this inhibition would become more and more significant with intervention period extending.

Using MG and inflammatory mediators as the targets had important practical significance in broadening the therapeutic approaches of SAE. Currently, the signaling pathways in MG had become the focus of numerous studies, including the JNK pathway [42], the MAPKs signaling pathway [32], the P38-MAPK signaling pathway, and the JNK signaling pathway [43], as well as the newly discovered possible inflammatory signaling pathways in MG [44]. This study mainly focused on the impacts of mild hypothermia on the LPS-induced TLR4/NF- $\mathrm{kB}$ signaling pathway in SAE, and found that mild hypothermia could delay the time bar of inflammatory responses; therefore it could save time for the treatment of SAE, and the combination of the above found therapeutic strategies and mild hypothermia might achieve better results.

This study suggested that the brain-protective effects of mild hypothermia might be realized by inhibiting the mRNA and protein expressions in the TLR4/NF- $\mathrm{KB}$ 
signaling pathway, thereby reducing the secretion of its downstream inflammatory cytokines TNF- $\alpha$ and IL-10, and reducing the inflammation damages. However, whether the protective effects of mild hypothermia were realized via influencing other proteins in the TLR4 signaling pathway still needed further researches.

The limitation of this study is that it is only found in cells cultured in vitro and needs to be further confirmed in the body, and even in the human body.

\section{Acknowledgements}

This study was supported by Natural Science Foundation of Anhui Province (No. 1808085MH308).

\section{Conflicts of Interest}

All authors have no conflict of interest regarding this manuscript.

\section{References}

[1] Chelazzi, C., Consales, G. and De Gaudio, A.R. (2008) Sepsis Associated Encephalopathy. Current Anaesthesia \& Critical Care, 19, 15-21. https://doi.org/10.1016/j.cacc.2007.07.009

[2] Gilmore, E.J., Gaspard, N., Choi, H.A., Cohen, E., Burkart, K.M., Chong, D.H., Claassen, J. and Hirsch, L.J. (2015) Acute Brain Failure in Severe Sepsis: A Prospective Study in the Medical Intensive Care Unit Utilizing Continuous EEG Monitoring. Intensive Care Medicine, 41, 686-694. https://doi.org/10.1007/s00134-015-3709-1

[3] Lu, Y.C., Yeh, W.C. and Ohashi, P.S. (2008) LPS/TLR4 Signal Transduction Pathway. Cytokine, 42, 145-151. https://doi.org/10.1016/j.cyto.2008.01.006

[4] Aravalli, R.N., Peterson, P.K. and Lokensgard, J.R. (2007) Toll-Like Receptors in Defense and Damage of the Central Nervous System. Journal of Neuroimmune Pharmacology, 2, 297-312. https://doi.org/10.1007/s11481-007-9071-5

[5] Ishizuka, F., Shimazawa, M., Inoue, Y., et al. (2013) Toll-Like Receptor 4 Mediates Retinal Ischemia/Reperfusion Injury through Nuclear Factor-KappaB and Spleen Tyrosine Kinase Activation. Investigative Ophthalmology \& Visual Science, 54, 5807-5816. https://doi.org/10.1167/iovs.13-11932

[6] Song, J., Oh, Y. and Lee, J.E. (2015) MiR-Let7A Modulates Autophagy Induction in LPS-Activated Microglia. Experimental Neurobiology, 24, 117-125. https://doi.org/10.5607/en.2015.24.2.117

[7] Franco, R. and Fernandez-Suarez, D. (2015) Alternatively Activated Microglia and Macrophages in the Central Nervous System. Progress in Neurobiology, 131, 65-86. https://doi.org/10.1016/j.pneurobio.2015.05.003

[8] Park, S.Y., Kim, Y.H. and Park, G. (2015) Cucurbitacins Attenuate Microglial Activation and Protect from Neuroinflammatory Injury through Nrf2/AREactivation and STAT/NF-kB Inhibition. Neuroscience Letters, 609, 129-136. https://doi.org/10.1016/j.neulet.2015.10.022

[9] Block, M.L. and Hong, J.S. (2005) Microglia and Inflammation-Mediated Neurodegeneration: Multiple Triggers with a Common Mechanism. Progress in Neurobiology, 76, 77-98. https://doi.org/10.1016/j.pneurobio.2005.06.004 
[10] Streit, W.J., Conde, J.R., Fendrick, S.E., et al. (2005) Role of Microglia in the Central Nervous System's Immune Response. Neurological Research, 27, 685-691.

[11] Gilgun-Sherki, Y., Rosenbaum, Z., Melamed, E., et al. (2002) Antioxidant Therapy in Acute Central Nervous System Injury: Current State. Pharmacological Reviews, 54, 271-284.

[12] Wu, M.H., Huang, C.C., Chio, C.C., Tsai, K.J., Chang, C.P., Lin, N.K. and Lin, M.T. (2016) Inhibition of Peripheral TNF- $\alpha$ and Downregulation of Microglial Activation by Alpha-Lipoic Acid and Etanercept Protect Rat Brain against Ischemic Stroke. Molecular Neurobiology, 53, 4961-4971. https://doi.org/10.1007/s12035-015-9418-5

[13] Fan, B., Dun, S.H., Gu, J.Q., Guo, Y. and Ikuyama, S. (2015) Pycnogenol Attenuates the Release of Proinflammatory Cytokines and Expression of Perilipin 2 in Lipopolysaccharide-Stimulated Microglia in Part via Inhibition of NF- $\kappa$ B and AP-1 Activation. PLoS ONE, 10, e0137837. https://doi.org/10.1371/journal.pone.0137837

[14] Kang, B.K., Kim, M.K., Kim, S.Y., Lee, S.J., Choi, Y.W., Choi, B.T. and Shin, H.K. (2015) Anti-Neuroinflammatory Effects of Uncaria sinensis in LPS-Stimulated BV2 Microglia Cells and Focal Cerebral Ischemic Mice. The American Journal of Chinese Medicine, 43, 1099-1115. https://doi.org/10.1142/S0192415X15500639

[15] Matsui, T., Yoshida, Y., Yanagihara, M., et al. (2014) Hypothermia at 35 Degrees C Reduces the Time-Dependent Microglial Production of Pro-Inflammatory and Anti-Inflammatory Factors That Mediate Neuronal Cell Death. Neurocritical Care, 20, 301-310. https://doi.org/10.1007/s12028-013-9911-5

[16] Kalita, J., Bastia, J., Bhoi, S.K., et al. (2015) Systemic Inflammatory Response Syndrome Predicts Severity of Stroke and Outcome. Journal of Stroke and Cerebrovascular Diseases, 24, 1640-1648. https://doi.org/10.1016/j.jstrokecerebrovasdis.2015.03.057

[17] Kim, F., Nichol, G., Maynard, C., Hallstrom, A., Kudenchuk, P.J., Rea, T., Copass, M.K., Carlbom, D., Deem, S., Longstreth, W.T., Olsufka, M. and Cobb, L.A. (2014) Effect of Prehospital Induction of Mild Hypothermia on Survival and Neurological Status among Adults with Cardiac Arrestra Randomized Clinical Trial. JAMA, 311, 45-52. https://doi.org/10.1001/jama.2013.282173

[18] Gancia, P. and Pomero, G. (2012) Therapeutic Hypothermia in the Prevention of Hypoxic-Ischaemic Encephalopathy; New Categories to Be Enrolled. The Journal of Matemal-Fetal \& Neonatal Medicine, 25, 94-96.

[19] Nakamura, Y., Si, Q.S. and Kataoka, K. (1999) Lipopolysaccharide-Induced Microglial Activation in Culture: Temporal Profiles of Morphological Change and Release of Cytokines and Nitric Oxide. Neuroscience Research, 35, 95-100. https://doi.org/10.1016/S0168-0102(99)00071-1

[20] Bhatia, H.S., Candelario-Jalil, E., de Oliveira, A.C., Olajide, O.A., Martínez-Sánchez, G. and Fiebich, B.L. (2008) Mangiferin Inhibits Cyclooxygenase-2 Expression and Prostaglandin E2 Production in Activated Ratmicroglial Cells. Archives of Biochemistry and Biophysics, 477, 253-258. https://doi.org/10.1016/j.abb.2008.06.017

[21] Iwashyna, T.J., Ely, E.W., Smith, D.M. and Langa, K.M. (2010) Long-Term Cognitive Impairment and Functional Disability among Survivors of Severe Sepsis. JAMA, 304, 1787-1794. https://doi.org/10.1001/jama.2010.1553

[22] Shah, F.A., Pike, F., Alvarez, K., Angus, D., Newman, A.B., Lopez, O., Tate, J., Kapur, V., Wilsdon, A., Krishnan, J.A., Hansel, N., Au, D., Avdalovic, M., Fan, V.S., Barr, R.G. and Yende, S. (2013) Bidirectional Relationship between Cognitive Function and Pneumonia. American Journal of Respiratory and Critical Care Medicine, 188, 586-592. https://doi.org/10.1164/rccm.201212-2154OC 
[23] Widmann, C.N. and Heneka, M.T. (2014) Long-Term Cerebral Consequences of Sepsis. The Lancet Neurology, 13, 630-636. https://doi.org/10.1016/S1474-4422(14)70017-1

[24] Tang, Z.H., Hu, J.T., Lu, Z.C., et al. (2014) Effect of Mild Hypothermia on the Expression of Toll-Like Receptor 2 in Lung Tissues with Experimental Acute Lung Injury. Heart, Lung and Circulation, 23, 1202-1207. https://doi.org/10.1016/j.hlc.2014.05.016

[25] Hiller, S., DeKroon, R., Xu, L., et al. (2014) Alpha-Lipoic Acid Protects Mitochondrial Enzymes and Attenuates Lipopolysaccharide-Induced Hypothermia in Mice. Free Radical Biology \& Medicine, 71, 362-367. https://doi.org/10.1016/j.freeradbiomed.2014.03.022

[26] Hakim, T.S., Pedoto, A., Nandi, J., Bosco, G., Rubini, A., Mangar, D., et al. (2014) Hypothermia Attenuates NO Production in Anesthetized Rats with Endotoxemia. Naunyn-Schmiedeberg's Archives of Pharmacology, 387, 659-665. https://doi.org/10.1007/s00210-014-0977-1

[27] Wang, S., Tang, Z., Hu, J., Jiang, L. and Yin, X. (2014) Impact of Hypothermia on Toll-Like Receptor 4 mRNA Transcription and Inflammatory Balance of Macrophage Induced by Lipopolysaccharide. Chinese Critical Care Medicine, 26, 84-88.

[28] Altinsoy, C., Tuzun, F., Duman, N., Sever, A.H., Dilek, M., Ozbal, S., et al. (2014) Effect of Induced Hypothermia on Lipopolysaccharide-Induced Lung Injury in Neonatal Rats. The Journal of Maternal-Fetal \& Neonatal Medicine, 27, 421-429. https://doi.org/10.3109/14767058.2013.818115

[29] Schwarzl, M., Seiler, S., Wallner, M., von Lewinski, D., Huber, S., Maechler, H., et al. (2013) Mild Hypothermia Attenuates Circulatory and Pulmonary Dysfunction during Experimental Endotoxemia. Critical Care Medicine, 41, e401-e410. https://doi.org/10.1097/CCM.0b013e31829791da

[30] Chang, Y.T., Wann, S.R., Tsai, J.S., Kao, C.H., Lee, P.T., Huang, N.C., et al. (2013) The Role of Autonomic Nervous System Function in Hypothermia-Mediated Sepsis Protection. The American Journal of Emergency Medicine, 31, 375-380. https://doi.org/10.1016/j.ajem.2012.08.028

[31] Kumar, A., Bhatia, H.S., de Oliveira, A.C. and Fiebich, B.L. (2015) microRNA-26a Modulates Inflammatory Response Induced by Toll-Like Receptor 4 Stimulation in Microglia. Journal of Neurochemistry, 135, 1189-1202. https://doi.org/10.1111/jnc.13364

[32] Wang, H.Y., Wang, H., Wang, J.H., Wang, Q., Ma, Q.F. and Chen, Y.Y. (2015) Protocatechuic Acid Inhibits Inflammatory Responses in LPS-Stimulated BV2 Microglia via NF- $\kappa$ B and MAPKs Signaling Pathways. Neurochemical Research, 40, 1655-1660. https://doi.org/10.1007/s11064-015-1646-6

[33] Kim, P.K. and Deutschman, C.S. (2000) Inflammatory Responses and Mediators. Surgical Clinics of North America, 80, 885-894.

https://doi.org/10.1016/S0039-6109(05)70102-X

[34] Yang, G.Y., Schielke, G.P., Gong, C., Mao, Y., Ge, H.L., Liu, X.H. and Betz, A.L. (1999) Expression of Tumor Necrosis Factor-Alpha and Intercellular Adhesion Molecule-1 after Focal Cerebral Ischemia in Interleukin-1beta Converting Enzyme Deficient Mice. Journal of Cerebral Blood Flow \& Metabolism, 19, 1109-1117. https://doi.org/10.1097/00004647-199910000-00007

[35] Zou, J.Y. and Crews, F.T. (2005) TNF Alpha Potentiates Glutamate Neurotoxicity by Inhibiting Glutamate Uptake in Organotypic Brain Slice Cultures: Neuroprotection by NF Kappa B Inhibition. Brain Research, 1034, 11-24. 
https://doi.org/10.1016/j.brainres.2004.11.014

[36] Tambuyzer, B.R., Ponsaerts, P. and Nouwen, E.J. (2009) Microglia: Gatekeepers of Central Nervous System Immunology. Journal of Leukocyte Biology, 85, 352-370. https://doi.org/10.1189/jlb.0608385

[37] Streit, W.J. (2002) Microglia as Neuroprotective, Immunocompetent Cells of the CNS. Glia, 40, 133-139. https://doi.org/10.1002/glia.10154

[38] Dai, X.J., Li, N., Yu, L., et al. (2015) Activation of BV2 Microglia by Lipopolysaccharide Triggers an Inflammatory Reaction in PC12 Cell Apoptosis through a Toll-Like Receptor 4-Dependent Pathway. Cell Stress Chaperones, 20, 321-331. https://doi.org/10.1007/s12192-014-0552-1

[39] Huang, R.L., Yuan, Y., Zou, G.M., et al. (2014) LPS-Stimulated Inflammatory Environment Inhibits BMP-2-Induced Osteoblastic Differentiation through Crosstalk between TLR4/MyD88/NF-kappaB and BMP/Smad Signaling. Stem Cells and Development, 23, 277-289. https://doi.org/10.1089/scd.2013.0345

[40] Guo, L., Li, S., Zhao, Y., et al. (2015) Silencing Angiopoietin-Like Protein 4 (ANGPTL4) Protects against Lipopolysaccharide-Induced Acute Lung Injury via Regulating SIRT1/NF-kB Pathway. Journal of Cellular Physiology, 230, 2390-2402. https://doi.org/10.1002/jcp.24969

[41] Zhu, J.P., Wu, K., Li, J.Y., et al. (2015) Cryptoporus volvatus Polysaccharides Attenuate LPS-Induced Expression of Pro-Inflammatory Factors via the TLR2 Signaling Pathway in Human Alveolar Epithelial Cells. Pharmaceutical Biology, 54, 1-7. https://doi.org/10.3109/13880209.2015.1060508

[42] Zhao, H., Cheng, L., Liu, Y., et al. (2014) Mechanisms of Anti-Inflammatory Property of Conserved Dopamine Neurotrophic Factor: Inhibition of JNK Signaling in Lipopolysaccharide-Induced Microglia. Journal of Molecular Neuroscience, 52, 186-192. https://doi.org/10.1007/s12031-013-0120-7

[43] Badshah, H., Ali, T., Rehman, S.U., Amin, F.U., Ullah, F., Kim, T.H. and Kim, M.O. (2016) Protective Effect of Lupeol against Lipopolysaccharide-Induced Neuroinflammation via the p38/c-Jun N-Terminal Kinase Pathway in the Adult Mouse Brain. Journal of NeuroImmune Pharmacology, 11, 48-60. https://doi.org/10.1007/s11481-015-9623-Z

[44] Ma, B., Yu, J., Xie, C., Sun, L., Lin, S., Ding, J., Luo, J. and Cai, H. (2015) Toll-Like Receptors Promote Mitochondrial Translocation of Nuclear Transcription Factor Nuclear Factor of Activated T-Cells in Prolonged Microglial Activation. Journal of Neuroscience, 35, 10799-10814. https://doi.org/10.1523/JNEUROSCI.2455-14.2015 